\title{
Successful Turnaround of a University- Owned, Community-Based, Multidisciplinary Practice Network
}

\author{
Michael K. Magill, $M D^{1,2,3}$ \\ Robin L. Lloyd, MPA ${ }^{3,4}$ \\ Duane Palmer, $M B A^{3}$ \\ Susan A. Terry, $M D^{2}$
}

'Department of Family and Preventive Medicine, University of Utah School of Medicine, Salt Lake City, Utah

${ }^{2}$ Community Physician Group, University of Utah Hospitals and Clinics, Salt Lake City, Utah

${ }^{3}$ Community Clinics, University of Utah Hospitals and Clinics, Salt Lake City, Utah

${ }^{4}$ Ambulatory Services, University of Utah Hospitals and Clinics, Salt Lake City, Utah

Conflicts of interest: none reported

\section{CORRESPONDING AUTHOR}

Michael K. Magill, MD

375 Chipeta Way, Suite A

Salt Lake City, UT 84108

Michael.Magill@hsc.utah.edu

\begin{abstract}
PURPOSE The University of Utah purchased a 100-clinician, 9-practice multispecialty primary care network in 1998. The university projected the network to earn a profit the first year of its ownership in a market with growing capitation; however, capitation declined and the network incurred up to a $\$ 21$ million operating loss per year. This case study describes the financial turnaround of the network.

METHODS In 2001, the university reconfigured the practices for a fee-forservice environment while preserving the group's multidisciplinary clinical and ancillary services. Changes included reorganization under the existing University of Utah Hospitals and Clinics system, new governance and leadership, closure of practices, creation of a billing office, new financial reporting, implementation of electronic health records, revision of physician compensation, capture of referrals, leadership and staff training, and practice reengineering.
\end{abstract}

RESULTS The network as a whole became profitable in 2004-2005. Its primary care component is projected to become profitable in 2 to 3 years. The network is opening new sites strategically important to the health system.

CONCLUSIONS This turnaround required commitment from senior university leaders, management with knowledge of primary care practice, retention of ancillary revenues, and management and business services specific to the network with support from other units within the university. Culture change within the group was essential. Our experience suggests that an academic health center can successfully operate a primary care network by attending to the unique needs of this challenging business. Doing so can strengthen the institution's overall financial and clinical performance and provide an important setting for teaching and research.

Ann Fam Med 2006;4(Suppl 1):S12-S18. DOI: 10.1370/afm.540.

INTROD practice networks, with disappointing results. Although some AHCs have reported changes leading to recovery of their health system as a whole,,$^{1-4}$ few have reported transforming major financial losses of university-owned, community-based outpatient systems into stable or profitable systems.

This report describes one such financial turnaround of a universityowned, community-based, multidisciplinary practice network. 


\section{METHODS \\ Setting}

In 1998, the University of Utah purchased a 100-

clinician multispecialty and primary care system with

9 outpatient practices remote from the university in the Salt Lake City metropolitan area, now known as the University of Utah Community Clinics. The university purchased the network with savings ("development accounts") generated by faculty members in the school of medicine that, although university property, were generally perceived as faculty resources to use for research, sabbaticals, and other purposes. The purchase price of $\$ 37.4$ million represented approximately $50 \%$ of the development account balances. Projected profit from the network in the first year of university ownership was expected to provide a return on investment to the development accounts. At the time of purchase, $34 \%$ of the Salt Lake County population were aged 19 years or younger, and $8 \%$ were aged 65 years or older. Seventy-five percent of the revenue of the purchased practices was derived from capitated health insurance payments. Profitability was projected based on expected growth in capitated payments.

\section{Initial Management}

The practice network was organized in the university as a business unit separate from the school of medicine and the University Hospital and Clinics, but was not incorporated separately from the university. It was governed by a board of directors, composed primarily of school of medicine department chairs and led by a central executive group. Central medical practice administration included 8 executive full-time equivalents (FTEs), and the medical practice network (not counting health plans or imaging) included about 87 FTE clinicians and 629 FTE staff. The network operated 3 major subunits: the medical practices themselves, a health plan, and a separate radiology practice. The practices were physician based for Medicare billing purposes. This report describes the medical practices and related ancillary services only.

\section{Initial Results}

The practice network generated immediate losses, peaking at more than $\$ 21$ million on approximately $\$ 80$ million in revenue in fiscal year 2000. Capitation decreased throughout the market. Lacking operating capital, the system drew on university reserves.

Organization of the network as a separate university business unit hindered effective collaboration with other university medical administrators and physicians to recognize and correct problems. Because the purchased group had provided largely capitated care, its billing, collection, and financial reporting capabilities were inadequate for fee-for-service practice. Physicians were paid salary without productivity incentives. Most inpatient and specialty referrals were sent to nonuniversity physicians and hospitals.

In 1999, a new university president and a new Vice President for Health Sciences/Dean of the School of Medicine, along with the board of regents and university trustees, faced a critical decision: whether to sell the network at a loss, writing off debt to the university and to faculty development accounts, or to restructure the network for profitability and to support the larger system by generating high-margin referrals. The former risked serious, lasting damage to the health system's market position. The latter posed a high risk of failure.

\section{Data Sources}

Information reported here about financial performance of the system came from internal management reports. Information about interventions to improve performance was derived from management records and participants' recollections.

\section{Authors' Perspective}

We authors helped lead the changes described herein. Dr Magill has been chairman of the Department of Family and Preventive Medicine at the University of Utah School of Medicine since before purchase of the network. Because of the relative size of reserves, his department was the second largest contributor of funds for the purchase. He served on the network's initial board of directors, before being appointed chairman of the reorganized board and then chief executive officer (CEO). Mr Lloyd joined the University of Utah in 2002. He had previously managed hospital-affiliated primary care practices and had spent 6 years consulting with hospitals to turn around failing primary care networks. Mr Palmer and Dr Terry implemented changes in the clinic operations and physician group, respectively.

\section{Changes}

Changes in the community clinics have occurred in 3 overlapping phases, outlined in Table 1 and described below.

\section{Phase I: Draconian Change}

Initial reorganization took about 2 to 3 years and entailed closing and relocating some of the existing practices. Administrative restructuring included appointment of a new board of directors, chairman/ $\mathrm{CEO}$, and senior management. The community clinics were moved under the administrative structure of the University of Utah Hospitals and Clinics. These changes led to layoffs of approximately 130 people, including executive staff (reduced from 8 FTEs to the 
Table 1. Operational Changes Implemented in University of Utah Community Clinics, 2000-2005

\begin{tabular}{|c|c|}
\hline $\begin{array}{l}\text { Phase of Change } \\
\text { (Approximate Time) }\end{array}$ & Examples of Changes \\
\hline $\begin{array}{l}\text { I: Draconian change } \\
\text { (years 1-2) }\end{array}$ & $\begin{array}{l}\text { Restructure organization, governance, and leadership } \\
\text { Restructure financing } \\
\text { Achieve "right size": match capacity to demand, close practices not } \\
\text { suited to fee for service or for referrals to the university }\end{array}$ \\
\hline $\begin{array}{l}\text { Il: Innovation and } \\
\text { performance } \\
\text { improvement } \\
\text { (year } 3 \text { onward) }\end{array}$ & $\begin{array}{l}\text { Develop financial and management reports } \\
\text { Revise physician compensation and benefits to incentivize produc- } \\
\text { tivity and sustainable levels } \\
\text { Implement correct core principles of successful group practices } \\
\text { - Focus on patient experience } \\
\text { - Match the right person to the right job } \\
\text { - Standardize procedures } \\
\text { - Design facilities for efficiency and patient service } \\
\text { - Exploit technology } \\
\text { - Improve communication } \\
\text { Redesign ambulatory practice operations } \\
\text { - Implement advanced access scheduling } \\
\text { - Reengineer the ambulatory visit to be patient centered and } \\
\text { physician efficient } \\
\text { - Strive for lean design } \\
\text { Implement robust electronic medical record through all clinics } \\
\text { Establish an active clinical quality improvement program } \\
\text { Develop new services and new practice sites }\end{array}$ \\
\hline $\begin{array}{l}\text { III: Integration with the } \\
\text { academic mission } \\
\text { (year } 4 \text { onward) }\end{array}$ & $\begin{array}{l}\text { Teaching } \\
\text { - Appoint physicians as adjunct faculty to the school of medicine } \\
\text { - Standardize educational contracts with outside institutions } \\
\text { - Allow elective rotations for students (medical, physician's assis- } \\
\text { tant, other) and residents } \\
\text { - Offer a continuity clinic for pediatrics residents } \\
\text { - Integrate outpatient family medicine residency/faculty clinics } \\
\text { in to community clinics network } \\
\text { Research } \\
\text { - Establish a research oversight committee: health sciences cen- } \\
\text { ter faculty, community clinics physicians and staff } \\
\text { - Develop principles and oversight for research: select research } \\
\text { that enhances the practices without disrupting operations } \\
\text { - Track projects and direct research expense using community } \\
\text { clinics (total to date approximately } \$ 2.5 \text { million) } \\
\text { - Establish formal practice-based research networks: } \\
\text { Utah Health Research Network, Utah Sports Research Network }\end{array}$ \\
\hline
\end{tabular}

current 2.75 FTEs), physicians, and about $18 \%$ of the workforce. Summary statistics on sites, staffing, visits, and active patients are shown in Table 2.

A new management structure paired a physician leader with an administrator at each of 3 levels. The full-time CEO position was divided into a part-time executive medical director position and a full-time executive director position. Within the community clinics, a medical director and administrative director report to the executive medical director and executive director. Each clinic network is led by a team of a medical director and a clinic manager, who are jointly accountable for its performance. The evolving profile of the clinics is summarized in Table 2. Current staffing is shown in more detail in Table 3.

Through the restructuring, the network retained certain features. In addition to primary medical care, the practices' ancillary services are included in network financial statements. Each practice includes full-service pharmacy, radiology, optician, and optical dispensing services. The system operates other services as shown in Table 4, many of which are not typically included in universityowned practice systems limited only to primary care, but which were purchased as an integrated unit and are still operated as such.

Table 2. Summary Profile of University of Utah Community Clinics, 1998-2005

\begin{tabular}{|c|c|c|c|}
\hline Characteristic & 1998 & 2000 & 2005 \\
\hline $\begin{array}{l}\text { No. of primary medical } \\
\text { practice sites }\end{array}$ & 9 & 8 & 7 \\
\hline Total clinician FTEs & 87 & 79 & 70 \\
\hline Physician FTEs & NA & 64 & 61 \\
\hline Midlevel clinician* FTEs & NA & 15 & 9 \\
\hline Staff FTEs & 629 & 516 & 483 \\
\hline No. of patient visits & NA & 216,430 & 263,605 \\
\hline No. of active patients & NA & NA & 105,300 \\
\hline
\end{tabular}

FTE = approximate full-time equivalents; NA = data not available.

* Physician's assistants (PAs), nurse-practitioners (NPs), and certified nursemidwives (CNMs)
The network mandated that referrals to specialists and hospitals outside the network be to the university.

Phase II: Innovation and Performance Improvement After the more severe changes initiated in the first phase, network leadership initiated the second, ongoing phase of culture change, operational improvement, clinical quality improvement, control of costs, and increase in revenue. A critical step in this process was to develop management and physician productivity reports specific to the needs of ambulatory practices. The practices were converted to hospital ("pro-

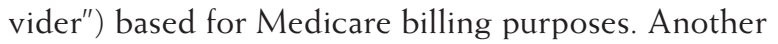
step was to implement an incentivized physician 


\begin{tabular}{lc|}
\hline Table 3. Employees of University of Utah \\
Community Clinics, 2005 & \\
\hline Employees & No.* \\
\hline Clinicians' & 121 \\
Main staff clinicians & 63 \\
Family medicine & 28 \\
Internal medicine & 11 \\
Pediatrics & 7 \\
Internal medicine/pediatrics & 2 \\
Obstetrics-gynecology & 5 \\
Gastroenterology & 2 \\
Podiatry & 2 \\
Physical medicine & 1 \\
Occupational medicine & 1 \\
Physical therapy & 4 \\
Other clinicians & 58 \\
Ski clinic (seasonal) & 12 \\
University of Utah visiting specialists & 10 \\
Moonlighters & 29 \\
Optometrists & 7 \\
Support staff & 483 \\
Total employees & 604 \\
\hline * Numbers shown refer to individuals, not full-time equivalents. \\
† Medical doctors (MDs), doctors of osteopathy (DOs), doctors of physical \\
medicine (DPMs), physician's assistants, nurse-practitioners (NPs), and certified \\
nurse-midwives (CNMs). \\
\hline
\end{tabular}

compensation system rewarding productivity at a level sustainable for the long term. A third step entails continued and repeated education for leadership, management, and clinicians.

\section{Phase III: Integration With the Academic Mission} Although the major focus has been on business performance of the clinics, they were also gradually integrated into the academic mission of the university. Growth of teaching in the practices has been gradual, as students and residents from multiple programs in the university and from elsewhere discover the opportunity to learn in these practices.

Growth of research has been more directed, with oversight from a joint committee of university faculty from multiple health professions schools along with physicians and management from the clinics. Research is selected based on its benefit to the practices and patients, and is managed in a way so as not to disrupt practice operations. In addition, practice innovations and clinical quality improvements developed at 1 site in the network can rapidly disseminate throughout the system. Table 5 summarizes research conducted to date in the clinics.

\section{RESULTS}

The financial performance of the community clinics improved steadily, as shown in Figure 1. The clinics
Table 4. Clinical and Business Services Provided Within University of Utah Community Clinics, 2005

\begin{tabular}{|c|c|}
\hline Clinical Services & Business Services \\
\hline $\begin{array}{l}\text { Primary care } \\
\text { Family medicine, internal medicine, } \\
\text { pediatrics, obstetrics-gynecology } \\
\text { Specialty care } \\
\text { Gastroenterology, cardiology, } \\
\text { orthopedics, podiatry, neurol- } \\
\text { ogy, dermatology, urology, phys- } \\
\text { ical medicine and rehabilitation } \\
\text { Urgent care } \\
\text { Vision } \\
\text { Ophthalmology, optometry, optical } \\
\text { Pharmacy } \\
\text { Laboratory } \\
\text { Radiology } \\
\text { Plain radiography, CT, mammog- } \\
\text { raphy, } \\
\text { nuclear medicine, US } \\
\text { Travel clinic and infectious disease } \\
\text { Endoscopy } \\
\text { Physical therapy } \\
\text { Ski clinic } \\
\text { DEXA scan }\end{array}$ & $\begin{array}{l}\text { Administrative } \\
\text { Executive leadership } \\
\text { Executive medical } \\
\text { director } \\
\text { Executive director } \\
\text { Chief operating officer } \\
\text { Group medical director } \\
\text { Clinic medical directors } \\
\text { Clinic management team } \\
\text { Support services } \\
\text { Central billing services } \\
\text { Marketing } \\
\text { Compliance } \\
\text { Payer contracting } \\
\text { Facilities management } \\
\text { Human resources }\end{array}$ \\
\hline
\end{tabular}

were profitable in the fiscal year ending June 2005. Profitable individual service lines were specialty care, pharmacy, laboratory, and optical services (Table 6). The remaining service line, primary care, is projected to become profitable in 2 to 3 years.

Separate from the network's direct income and expenses, other University of Utah specialist physicians and University Hospital generated more than $\$ 5$ million gross revenue per month from referrals originating in the network.

\section{DISCUSSION}

This report describes the successful financial turnaround over 5 years of a university-owned multidisciplinary outpatient clinical care system. As is typical for strategic change across industries, the turnaround occurred in phases to reduce cost, to reorganize operations, and to incorporate academic missions. ${ }^{7.9}$

\section{Lessons Learned}

Lessons learned from this experience include the following:

1. "Yagottawanna." Motivation to fix the problem was present at all levels: the university had to either accept a substantial reduction in its reserves or correct the system to generate margin in a fee-for-service market. Senior university leaders needed to be patient 
Table 5. Research Projects Using Community Clinics, 2000-2005

\begin{tabular}{|c|c|c|c|}
\hline Project Title & $\begin{array}{c}\text { PI's/Coinvestigator's Home } \\
\text { Department (School of Medicine) } \\
\text { or Other College }\end{array}$ & Funding Source & $\begin{array}{l}\text { Total Direct } \\
\text { Costs, \$ }\end{array}$ \\
\hline Cutaneous Measures of Diabetic Neuropathy & Internal Medicine & $\mathrm{NIH}$ & $1,345,705$ \\
\hline Time to Pregnancy in Normal Fertility & Family and Preventive Medicine & $\mathrm{NIH}$ & 499,995 \\
\hline $\begin{array}{l}\text { Impact of Electronic Reminders on Screening for } \\
\text { Colon Cancer }\end{array}$ & $\begin{array}{l}\text { Huntsman Cancer Institute, Family } \\
\text { and Preventive Medicine }\end{array}$ & $\mathrm{NIH}$ & 247,500 \\
\hline The Safety Check & Family and Preventive Medicine & $\mathrm{NIH}, \mathrm{AHRQ}$ & 200,000 \\
\hline $\begin{array}{l}\text { Pharmacological Mechanisms of Falls and Sway } \\
\text { in the Elderly }\end{array}$ & College of Nursing & $\begin{array}{l}\text { National Institute of } \\
\text { Nursing Research }\end{array}$ & 150,000 \\
\hline Genital Herpes Prevention Study & Internal Medicine & $\mathrm{NIH}$, industry & 100,000 \\
\hline $\begin{array}{l}\text { Insulin Glargine Treatment Patterns in the Manage- } \\
\text { ment of Diabetes, Type I and Type II }\end{array}$ & College of Pharmacy & Industry & 65,000 \\
\hline Effects of Various Drugs on Hypoglycemic Events & College of Pharmacy & Industry & 65,000 \\
\hline Chronic Back Pain & Anesthesiology & Foundation & 50,000 \\
\hline Bioterrorism Surveillance & Family and Preventive Medicine & Foundation & 35,000 \\
\hline $\begin{array}{l}\text { Determinants of Exercise in Obese and Nonobese } \\
\text { Sedentary Pregnant Women }\end{array}$ & Family and Preventive Medicine & $\begin{array}{l}\text { Department of Family and } \\
\text { Preventive Medicine's } \\
\text { Small Grants Program }\end{array}$ & 25,000 \\
\hline Asthma Guideline Adherence: Implications for Cost & College of Pharmacy & Department of Pediatrics & 25,000 \\
\hline $\begin{array}{l}\text { Measurement and Prevalence of Deformational } \\
\text { Plagiocephaly }\end{array}$ & $\begin{array}{l}\text { Pediatrics, Family and Preventive } \\
\text { Medicine }\end{array}$ & AHRQ & 20,000 \\
\hline Population Surveillance to Detect an Epidemic & Family and Preventive Medicine & Foundation & 20,000 \\
\hline ADHD Patient Weight Distribution Study & College of Pharmacy & Industry & 10,000 \\
\hline $\begin{array}{l}\text { Developing a Research Tool to Accurately Measure } \\
\text { Latinos' Perceived Barriers to Health Care }\end{array}$ & Family and Preventive Medicine & Foundation & 5,600 \\
\hline Other & - & - & 12,500 \\
\hline $\begin{array}{l}\text { Total direct costs of research using community } \\
\text { clinics }\end{array}$ & - & - & $2,876,300$ \\
\hline
\end{tabular}

Figure 1. Financial bottom line (profit or loss) of University of Utah Community Clinics.

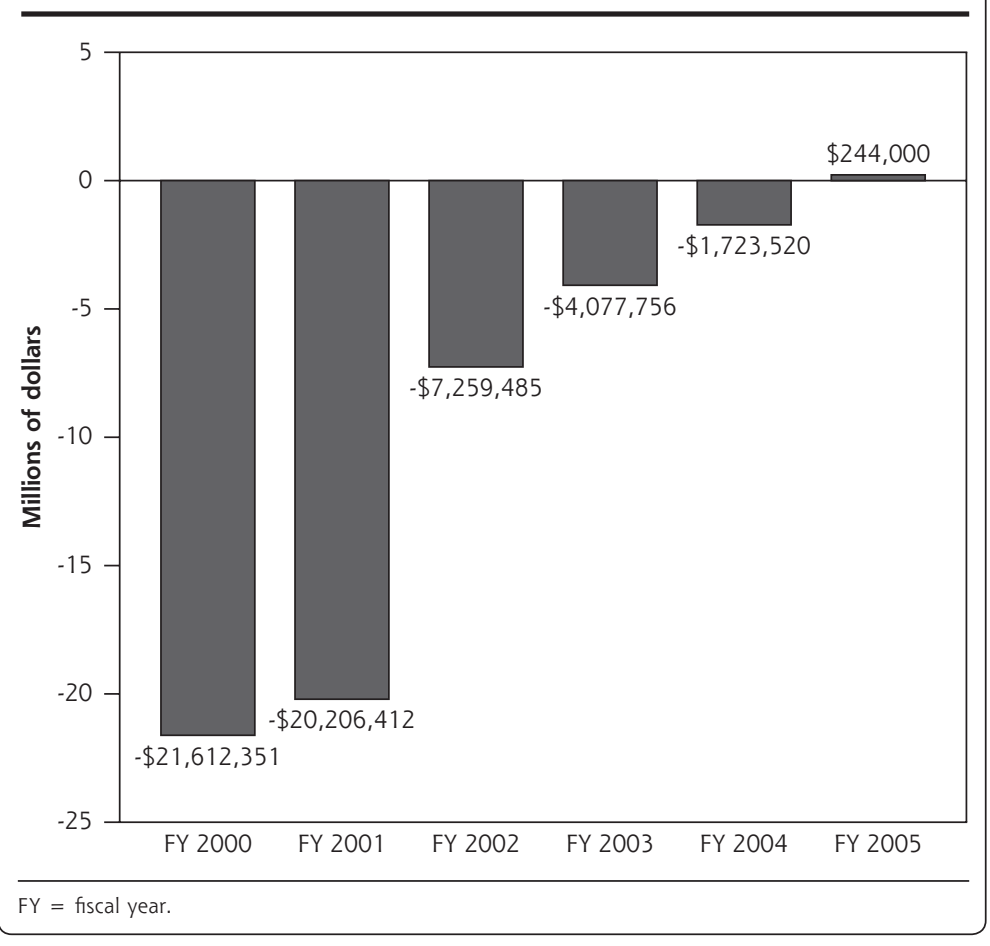

with the process of improvement and stand firm in their decisions despite substantial anger from faculty and criticism in the press. A primary care physician faculty member and a dedicated practice management executive believed in the potential for the system and its vital importance to the university, and were committed to succeeding. Senior leadership with expertise specific to the management of outpatient practices, as well as committed to and accountable for the success of the project is essential.

2. "You must reward productivity, but it's not all about productivity." A physician incentive system, set to reward physicians' productivity at sustainable levels, is important. Equally important in the longer term is a commitment to redesigning the clinical practice operation to support physician success by providing robust clinical and financial information systems, adequate staff support, and efficient, patient-centered care. Examples of key elements of practice 
Table 6. Income Statement (\$000) by Service Line, Fiscal Year 2005 (July 2004 to June 2005)

\begin{tabular}{lccccrrr}
\hline Measure & $\begin{array}{c}\text { Primary } \\
\text { Care }\end{array}$ & $\begin{array}{c}\text { Specialty } \\
\text { Care }\end{array}$ & $\begin{array}{c}\text { Central } \\
\text { Laboratory }\end{array}$ & Pharmacy & $\begin{array}{c}\text { Vision } \\
\text { Services }\end{array}$ & $\begin{array}{c}\text { Central } \\
\text { Administration }\end{array}$ & Total \\
\hline Total net revenue (loss) & 16,884 & 9,537 & 2,335 & 24,214 & 2,922 & $(321)$ & 55,570 \\
Total expense & 21,125 & 6,016 & 1,228 & 19,599 & 2,554 & 4,825 & 55,347 \\
Net income (loss) & $(4,241)$ & 3,521 & 1,106 & 4,616 & 368 & $(5,146)$ & 224 \\
\hline Note: Values do not add exactly because of rounding. & & & &
\end{tabular}

redesign include robust electronic medical records and financial information systems developed specifically for outpatient practices. In addition, the organization should provide adequate staff support and engineer practices for efficient, patient-centered care with features such as advanced access ${ }^{10}$ and lean design. ${ }^{11}$

3. "This ain't your grandfather's hospital clinic." Community-based practice requires internal operations and information different from those required by a hospital or its specialty clinics. A network is unlikely to succeed with separate functional departments typical in hospitals or with administrative divisions between staff clinicians. Interdisciplinary teamwork and integrated leadership and management are essential.

4. "You can't cost cut your way to profitability. The game is won on the revenue side." Hospitals typically impose overhead expenses higher than those carried by independent physician practices. Primary care requires adequate volume to generate profit above the large component of fixed costs.

5. "Don't take away the profitable services and then blame the system for its losses." Primary care practice generates more profit from procedural and ancillary services than from evaluation and management services. University-owned systems should allow primary care systems to retain revenues from procedural and ancillary services as part of an integrated system. While this approach may reduce the apparent "multiplier effect" of downstream revenue, it does so by retaining within the practice network services and accompanying revenues that are often located elsewhere. ${ }^{12}$

6. "Plan from the beginning for the practice network to become a 'laboratory and classroom."' As part of academic institutions, these practices are excellent resources for research and teaching, particularly when the practices incorporate full-featured electronic medical records. Universities have as part of their missions the development of new approaches to patient care. These practices can be useful sites for innovation in practice design and operation, ${ }^{13}$ for quality improvement, and for research to characterize illness in primary care, as well as for more tradi- tional clinical trials. Also, with translational research increasingly recognized as essential ${ }_{1}^{14}$ practice-based research networks such as this one are critical to the 2-way exchange of learning along the continuum between the laboratory bench and improved quality of patient care. ${ }^{15}$

As medical practice becomes increasingly based in ambulatory settings, these practice networks give universities teaching sites away from the increasingly rarified atmosphere of the academic health center. Also, university ownership may provide more reliable access to such sites as private practices under increasing financial pressures become less available.

Leadership by medical school faculty committed to excellence in primary care, such as faculty in a department of family medicine, can help make the business, clinical, and academic agendas of the practice network mutually reinforcing.

\section{Limitations}

This report describes only 1 health care system. Circumstances specific to its purchase, its mix of services, its operating strengths and weaknesses, and the market may make the described events less applicable to other settings. This report was written by individuals accountable for results and directly involved in developing and implementing the turnaround plans. Other observers might have identified different issues and described the changes differently. Because this intervention was complex and multidimensional and had no control group, it is not possible to determine the relative impact of individual changes on the outcome.

\section{Future Directions}

We continue to improve volume, revenue, quality, access, and patient satisfaction. This system improvement is tied to a rapid increase in research and teaching in the network and its full integration into all missions of the academic health center.

To read or post commentaries in response to this article, see it online at http://www.annfammed.org/cgi/content/full/4/suppl_1/s12

Key words: Financial performance; economics; fee for service; academic health centers; health care systems; organizational change; primary care; organization and administration 
Submitted September 22, 2005; submitted, revised, January 20, 2006; accepted January 30, 2006.

Portions of this material have been presented at meetings of the Association of Departments of Family Medicine, February 2004, San Diego, Calif; the Society of Teachers of Family Medicine, May 2004, Toronto, Ontario; the American Medical Group Association, March 2005, Los Angeles, Calif, and September 2005, Chicago, IIl; and the Association of American Medical Colleges, November 2005, Washington, DC.

Acknowledgments: The authors thank the senior leadership of the University of Utah and the University of Utah Hospitals and Clinics, and board members, physicians, and staff of the University of Utah Community Clinics for sponsoring and implementing the changes necessary to accomplish the results described herein. Thanks to Richard Murdock for comments on the text and to Mary McFarland for assistance with the literature review.

\section{References}

1. Karpf M, Schultze RG, Levey G. The decade of the nineties at the UCLA Medical Center: responses to dramatic marketplace changes. Acad Med. 2000;75:781-792

2. Saxton JF, Blake DA, Fox JT, Johns MM. The evolving academic health center: strategies and priorities at Emory University. JAMA. 2000;283:2434-2436.

3. Rodin J. A revisionist view of the integrated academic health center Acad Med. 2004:79:171-178.

4. Malvey D, Hyde JC, Topping S, Woodrell FD. Getting off the bandwagon: an academic health center takes a different strategic path. J Healthc Manag. 2000;45:381-393; discussion 393-394.
5. Blumenthal D, Weissman JS. Selling teaching hospitals to investorowned hospital chains: three case studies. Health Aff (Millwood). 2000;19:158-166.

6. Walsh AM, Szabat K. Sustaining the edge: factors influencing strategy selection in academic health centers. J Healthc Manag. 2002;47:360-374; discussion 375

7. Skivington JE, Daft RL. A study of organizational 'framework' and 'process' modalities for the implementation of business-level strategic decisions. J Manage Stud. 1991;28:45-67.

8. Harmon J, Scotti DJ, Behson S, et al. Effects of high-involvement work systems on employee satisfaction and service costs in veterans healthcare. J Healthc Manag. 2003;48:393-406; discussion 406-407.

9. Studer Q. Hardwiring Excellence. Gulf Breeze, Fla: Fire Starter Publishing; 2003.

10. Murray M, Berwick DM. Advanced access: reducing waiting and delays in primary care. JAMA. 2003;289:1035-1040.

11. Endsley S, Magill MK, Godfrey MM. Creating a lean practice. Fam Pract Manag. 2006;13:34-38.

12. Saultz JW, McCarty G, Cox B, et al. Indirect institutional revenue generated from an academic primary care clinical network. Fam Med. 2001;33:668-671.

13. Endsley S, Kirkegaard M, Magill M, Hickner J. Innovation in prac tice: six ways to harness the power of your ideas. Fam Pract Manag. 2005;12:37-40.

14. Zerhouni EA. Translational and clinical science-time for a new vision. N Engl J Med. 2005;353:1621-1623.

15. Lanier D. Primary care practice-based research comes of age in the United States. Ann Fam Med. 2005:3(Suppl 1):S2-S4 